\title{
Penerapan Metode Diskusi Berbasis WA Grup untuk Meningkatkan Prestasi Belajar Siswa pada Mata Pelajaran Matematika Materi Persamaan Trigonometri di SMAN 4 Kota Bima Kelas XI MIPA 3 Semester Ganjil Tahun Pelajaran 2020/2021
}

\author{
Nurmiyati \\ SMA Negeri 4 Kota Bima, Kota Bima, Indonesia \\ *Coresponding Author: nnurmiyati@ gmail.com \\ Dikirim: 19-08-2021; Direvisi: 24-10-2021; Diterima: 25-10-2021
}

\begin{abstract}
Abstrak: Hasil refleksi penelitian pra-sklus menunjukan, rendahnya prestasi belajar siswa ini ditunjukkan dengan indikator tara-rata 65.00 dengan ketuntasan klasikal $68.00 \%$. Hal ini masih dibawah indikator kinerja yang ditentukan yakni rata-rata $\geq 72.00$ dengan ketuntasan klasikal $\geq 80.00 \%$. Berdasarkan latar belakang masalah tersebut peneliti merumuskan masalah sebagai berikut: "Bagaimanakah penerapan metode diskusi berbasis WhatsApp Grup untuk meningkatkan prestasi belajar siswa pada mata pelajaran Matematika materi persamaan trigonometri semester I Kelas XI MIPA.3 SMAN 4 Kota Bima Tahun Pelajaran 2020/2021". Tujuan perbaikan dalam penelitian ini adalah 1. Mendeskripsikan penerapan metode diskusi berbasis WhatsApp group untuk meningkatkan prestasi belajar siswa pada mata pelajaran Matematika materi persamaan trigonometri di SMAN 4 Kota Bima Kelas XI MIPA.3 semester ganjil Tahun Pelajaran 2020/2021. 2. Menganalisis dampak penerapan metode diskusi berbasis WhatsApp Group dalam meningkatkan prestasi belajar siswa pada mata pelajaran Matematika materi persamaan trigonometri di SMAN 4 Kota Bima kelas XI MIPA.3 semester ganjil Tahun Pelajaran 2020/2021. Subyek perbaikan adalah siswa-siswi Kelas XI MIPA.3 SMAN 4 Kota Bima jumlah siswa 32 terdiri dari 15 orang laki-laki dan 17 orang perempuan. Perbaikan dilaksanakan dalam 2 (dua) siklus. Siklus I dari tanggal 03 Agustus 2020 sampai dengan 18 Agustus 2020 dan siklus II dilaksanakan tanggal 8 September 2020 sampai dengan 20 September 2020. Teknik pengumpulan data meliputi pengamatan, dokumen dan tes. Peningkatan prestasi belajar siswa ini dapat dibandingkan dari hasil tes pra-perbaikan. Hasil pos tes siklus I diatas menunjukkan bahwa prestasi belajar siswa rata-rata $68.44(+3.44)$, Persentase ketuntasan $71.00 \%(+3.00)$, Persentase ini masih dibawah indikator kinerja yakni $\geq 80.00 \%$. Dari sisi prestasi belajar siklus I (pertama) belum berhasil. Skor kinerja guru kompetensi guru dalam perencanaan pembelajaran APKG I pada siklus I $\geq 88.50(+0.50)$ APKG II, untuk pelaksanaan pembelajaran yang mendidik $\geq 86.00$ $(+1.00)$ tetapi masih terdapat 7 deskriptor yang sebagian dilaksanakan (sebagain terpenuhi) dan 4 deskriptor seluruhnya dilaksanakan (seluruhnya terpenuhi). Dengan demikian dari sisi kinerja guru siklus I belum mencapai indikator kinerja yang ditetapkan yakni APKG I $\geq 89.00$ APKG II $\geq 88.00$. Hasil pos tes siklus II diatas menunjukkan bahwa prestasi belajar siswa rata-rata $75.00(+6.56)$. Persentase ketuntasan $82.00 \%,(+11.00)$. Persentase ini telah memenuhi indikator kinerja yakni $\geq 80.00 \%$. Dengan demikian pada siklus II ini telah berhasil mencapai indikator yang ditetapkan yakni rata-rata $\geq 72.00$ dan persentase ketuntasan $\geq 80.00 \%$. Dari sisi prestasi belajar siklus II (kedua) telah berhasil. Skor kinerja guru menunjukkan bahwa skor ketuntasan guru dalam perencanaan pembelajaran APKG I dengan porsentase $\geq 90.00(+1.50)$ APKG, II untuk pelaksanaan pembelajaran yang mendidik $\geq 89.00$ ( +3.00$)$. Dengan perbaikan proses pembelajaran berhasil memenuhi indikator kinerja yang ditetapkan yakni APKG I, untuk perencanaan $\geq 89.00$ APKG II, untuk pelaksanaan $\geq 88.00$. Peningkatkan prestasi belajar siswa, disebabkan oleh peningkatan aktivitas, interaksi guru dan siswa dalam proses pembelajaran di kelas dengan penerapan metode diskusi berbasis WhatsApp Messenger yang dilaksanakan guru, sesuai dengan nilai kinerja guru.
\end{abstract}


Dengan demikian setelah pelaksanaan perbaikan pembelajaran sampai siklus II, telah mencapai indikator kinerja yang ditetapkan, dan penelitian dianggap telah berhasil.

Kata Kunci: Prestasi belajar siswa; metode diskusi; WhatsApp Group

Abstract: The results of the reflection of pre-cycle research show that the low learning achievement of students is indicated by an average indicator of 65.00 with a classical completeness of $68.00 \%$. This is still below the specified performance indicator, which is an average of 72.00 with a classical completeness of $80.00 \%$. Based on the background of the problem, the researcher formulates the problem as follows: "How is the application of the WhatsApp Group-based discussion method to improve student achievement in the Mathematics subject for the first semester of trigonometric equations in Class XI MIPA.3 SMAN 4 Kota Bima in the 2020/2021 academic year". The purpose of the improvements in this study are 1. To describe the application of the WhatsApp group-based discussion method to improve student achievement in the Mathematics subject of trigonometric equations at SMAN 4 Kota Bima Class XI MIPA. 3 odd semester of the 2020/2021 academic year. 2. Analyzing the impact of the application of the WhatsApp Group-based discussion method in improving student achievement in the Mathematics subject of trigonometric equations at SMAN 4 Kota Bima class XI MIPA.3 odd semester of the 2020/2021 academic year. The subjects of the improvement were students of Class XI MIPA.3 SMAN 4 Kota Bima with 32 students consisting of 15 boys and 17 girls. Repairs are carried out in 2 (two) cycles. Cycle I from 03 August 2020 to 18 August 2020 and cycle II was held from 8 September 2020 to 20 September 2020. Data collection techniques included observations, documents and tests. This increase in student achievement can be compared from the results of the pre-improvement test. The results of the post-test cycle I above show that the average student achievement is $68.44(+3.44)$, the percentage of completeness is $71.00 \%(+3.00)$, this percentage is still below the performance indicator, namely $80.00 \%$. In terms of learning achievement, the first (first) cycle has not been successful. Teacher performance score of teacher competence in learning planning APKG I in cycle I 88.50 $(+0.50)$ APKG II, for the implementation of educational learning $\geq 86.00(+1.00)$ but there are still 7 descriptors which are partially implemented (partly fulfilled) and 4 descriptors are entirely implemented (all fulfilled). Thus, in terms of teacher performance in cycle I, the performance indicators have not yet reached the set performance indicators, namely APKG I 89.00 APKG II 88.00. The results of the post-test cycle II above show that the average student achievement is $75.00(+6.56)$. The percentage of completeness is $82.00 \%,(+11.00)$. This percentage has met the performance indicator of $80.00 \%$. Thus, in the second cycle, it has succeeded in achieving the specified indicators, namely an average of 72.00 and a percentage of completeness $80.00 \%$. In terms of learning achievement, cycle II (second) has been successful. The teacher's performance score shows that the teacher's mastery score in learning planning APKG I with a percentage of $90.00(+1.50)$ APKG, II for the implementation of educational learning $89.00(+3.00)$. By improving the learning process, the performance indicators have been met, namely APKG I, for planning 89.00 APKG II, for implementation 88.00. The increase in student learning achievement was caused by an increase in activity, teacher and student interaction in the learning process in the classroom with the application of the WhatsApp Messenger-based discussion method carried out by the teacher, according to the teacher's performance score. Thus, after the implementation of learning improvements up to cycle II, the performance indicators have been achieved, and the research is considered successful.

Keywords: student learning achievement; discussion method; WhatsApp Groups

\section{PENDAHULUAN}


Sejak terjadi pandemi covid-19, proses pembelajaran di Tingkat SMA mengalami hambatan yang luar biasa, bahkan pada waktu-waktu tertentu pembelajaran benar-benar tidak dapat berjalan sebagaimana mestinya. Hal yang sama terjadi di SMAN 4 Kota Bima, dimana proses pembelajaran tidak dapat optima selama pandemi covid-19. Proses pembelajaran yang penliti lakukan sebagai guru mata pelajaran Matematika di Kelas XI MIPA.3 mengalami hambatan serupa. Di satu sisi siswa dan guru terbiasa pembelajaran tatap muka, di sisi lain proses pembelajaran tatap muka mengalami dinamika sesuai dengan kondisi covid-19 yang terjadi di lingkungan sekolah. Dengan demikian kalaupun ada jadwal tatap muka selama covid-19, waktunya tidak seperti sebelum terjadinya pandemi covid-19. Demikian pula kondisi psikologis siswa tidak sama seperti sebelum pandemi covid19.

Kondisi ini mendorong peneliti sebagai guru untuk mengupayakan bagaimana dengan beradaptasi kondisi yang ada bisa melaksanakan pembelajaran yang efektif. Karena SMAN 4 Kota Bima telah menerapkan Kurikulum 2013, dalam proses pembelajaran khususnya pada mata siswa Matematika Kelas XI MIPA.3, materi persamaan trigonometri pada pra peneltian, pra siklus, sebelum perbaikan pembelajaran sulit diterapkan. Peneliti memanfaatkan waktu yang terbatas dalam pembelajaran tatap muka untuk menyampaikan materi pembelajaran sementara untuk tugas dan tes, peneliti menggunakan sistem jemput antar. Artinya siswa menjeput tugas-tugas dan soal pos tes yang disiapkan oleh guru di sekolah sesuai dengan jadwal penjemputan, seanjutnya daam batas waktu yang ditentukan siswa mengantar tugas atau soal yang dikerjakan ke sekolah kembaali secara manual. Dengan cara tersebut terdapat kendala-kendala sebagai berikut:

1. Terdapat siswa yang tidak mengambil tugas, soal sesuai dengan jadwal yang ditentukan.

2. Terdapat siswa yang tidak mengumpulkan hasil tugas dan atau soal yang sesuai dengan jadwal yang ditetapkan.

3. Guru kesulitan memonitor aktivitas siswa di rumah dalam mengerjakan tugas atau soal tersebut.

4. Guru kesulitan memberikan umpan balik terhadapa tugas dan soal yang diberiikan guru baik secara kelompok maupun indvidual.

Permasalahan-permasalahan tersebut menjadikan kendala serius bagi peneliti sekaligus menjadikan proses pembelajaran tidak efektif yang berdampak pada prestasi belajar siswa yang rendah. Rendahnya prestasi belajar siswa ini ditunjukkan dengan indikator tara-rata 65.00 dengan ketuntasan klasikal $68.00 \%$. Hal ini masih dibawah indikator kinerja yang ditentukan yakni rata-rata $\geq 72.00$ dengan ketuntasan klasikal $\geq 80.00 \%$. Demikian pula kinerja guru yang diukur dengan APKG 1 , untuk perencanaan pembelajaran dan APKG 2, untuk pelaksanaan pembelajaran rendah. Nilai APKG 1, untuk perencanaan pembelajaran 88.00 dan APKG 2, pelaksanaan pembelajaran 85.00. Nilai ini dibawah indikator knerja guru yang ditetapkan yakni APKG 1, untuk perencanaan pembelajaran 89.00 dan APKG 2, pelaksanaan pembelajaran 88.00.

Berdasarkan hasil refleksi awal tersebut peneliti berupaya mencari solusi khususnya pada 4 (empat) permasalahan mendasar yang telah diuraikan diatas. Dengan mengamati kondisi peneliti sendiri, kondisi sekolah serta kondisi siswa di Kelas XI MIPA.3, maka terdapat hal-hal positif yakni: 
1. Seluruh siswa telah memiliki smartphone berbasis android dan telah memiliki WA.

2. Seluruh siswa dapat mengoperasikan WA baik menerima, mengirim dan mengakses data.

3. Seluruh siswa dapat mengakses internet melalui smartphone.

Dengan konsep Kurikulum 2013 yang mengedepankan pencapaian kompetensi membawa konsekuensi bahwa pembelajaran harus berpusat pada siswa. Siswa didorong untuk terlibat aktif dan komprehensif dalam pembelajaran. Keterlibatan siswa secara aktif dan komprehensif tersebut akan memberikan pemahaman mendalam dan peluang besar pada pengalaman belajar yang berada di long term memory.

Dalam masa pandemi covid-19, kondisi ideal sesuai yang dihajatkan Kurikulum 2013 tersebut belum terlaksana para pra-siklus, pra penelitian, sehingga berdampak pada rendahnya prestasi belajar dan kinerja guru pada mata siswa Matematika Kelas XI MIPA.3, materi persamaan trigonometri.

Mengamati faktor-faktor kelebihan dan kekurangan selama covid-19, maka peneliti berupaya meminimalisir dampak kekurangan dan mengoptimalkan dampak kelebihan yakni dengan melaksanakan proses pembelajaran berbasis blended learning kombinasi pembelajaran tatap muka dan daring (online). Metode yang digunakan adalah metode diskusi baik tatap muka maupun daring (online), sedangkan dalam pembelajaran daring menggunaan WhatsAps messenger. Dari aspek efektivitas menjadi lasan pemilihan metode diskusi dan WhatsAps messenger yang selanjutnya dalam penelitian ini digunakan istilah yanng sudah lazim yakni WA Grup tersebut dalam blended learning. Menurut Sanjaya yang dikutip oleh Jumanta Hamdayama, metode pembelajaran diskusi adalah pembelajaran yang menekankan kepada proses penyampaian materi secara verbal dari seorang guru kepada sekelompok siswa dengan maksud agar siswa tidak jenuh saat belajar (Hamdayana, 2011). Metode ini sesuai dengan koondisi saat ini dan cocok bila dikmbinaikan dengan penggunaan WhatsAps messenger.

Penggunaan blended learning ini akan menjebatani perbedaan pembelajaran konvensional, dan pembelajaran daring (online). Dalam pembelajaran konvensional guru dianggap sebagai orang yang serba tahu dan ditugaskan untuk menyalurkan ilmu pengetahuan kepada siswanya. Sedangkan di dalam pembelajaran daring (online) fokus utamanya adalah siswa. Siswa mandiri pada waktu tertentu dan bertanggungjawab untuk pembelajarannya. Suasana pembelajaran daring (online) akan "memaksa" siswa memainkan peranan yang lebih aktif dalam pembelajarannya. Siswa membuat perancangan dan mencari materi dengan usaha, dan inisiatif sendiri. Khoe Yao Tung (2000) mengatakan bahwa setelah kehadiran guru dalam arti sebenarnya, internet akan menjadi suplemen dan komplemen dalam menjadikan wakil guru yang mewakili sumber belajar yang penting di dunia. (Supriani, 2017).

\section{KAJIAN TEORI}

\section{Hakikat Belajar dan Pembelajaran}

Belajar merupakan unsur yang sangat fundamental dalam penyelenggaraan setiap jenis dan jenjang pendidikan. Berbagai pendapat untuk menjelaskan pengertian belajar telah dilontarkan para ahli. Menurut R. Gagne (dalam Susanto 
2013:1), belajar dapat didefinisikan sebagai suatu proses dimana suatu organisme berubah perilakunya sebagai akibat pengalaman. Adapun menurut Burton dalam Usman dan Setiawati (Susanto 2013:1), belajar dapat diartikan sebagai perubahan tingkah laku pada diri individu berkat adanya interaksi antara individu dengan individu lain dan individu dengan lingkungannya sehingga mereka lebih mampu berinteraksi dalam lingkungannya. Sementara menurut Hamalik (dalam Susanto 2013:1), menjelaskan bahwa belajar adalah memodifikasi atau memperteguh perilaku melalui pengalaman (learning is defined as the modificator or strengthening of behavior through experiencing). Dengan demikian, belajar itu bukan sekadar mengingat atau menghafal saja, namun lebih luas dari itu merupakan mengalami.

Dari beberapa pengertian tersebut, dapat ditarik kesimpulan bahwa belajar adalah suatu aktivitas yang dilakukan seseorang dengan sengaja dalam keadaan sadar untuk memperoleh suatu konsep, pemahaman, atau pengetahuan baru sehingga memungkinkan sesorang terjadinya perubahan perilaku yang relatif tetap baik dalam berpikir, merasa, maupun dalam bertindak.

Komalasari (2013:3) menyatakan prinsip-prinsip yang harus diperhatikan dalam belajar meliputi:

1) Prinsip Kesiapan

Tingkat keberhasilan belajar tergantung pada kesiapan siswa. Dalam hal ini konsentrasi dan kondisi fisik seorang siswa akan berpengaruh terhadap proses belajar.

2) Prinsip Asosiasi

Tingkat keberhasilan belajar juga tergantung pada kemampuan siswa mengasosiasikan atau menghubungkan apa yang sedang disiswai dengan apa yang sudah ada dalam ingatannya.

3) Prinsip Latihan

Pada dasarnya memsiswai sesuatu itu perlu berulang-ulang, baik memsiswai pengetahuan maupun keterampilan, bahkan juga dalam kawasan afektif.

4) Prinsip Efek (Akibat)

Situasi emosional pada saat belajar akan memengaruhi prestasi belajarnya.

Situasi emosional itu dapat disimpulkan sebagai perasaan senang atau tidak senang selama belajar.

Pembelajaran merupakan kegiatan yang dilakukan untuk menginiasiasi, memfasilitasi, dan meningkatkan intensi dan kualitas belajar pada diri peserta didik (Winataputra 2008:1.18). Sementara menurut Gagne, Briggs, dan Wager (dalam Winataputra 2008:1.19), pembelajaran adalah serangkaian kegiatan yang dirancang untuk memungkinkan terjadinya proses belajar pada siswa. Instruction is a set of events that affect learners in such a way that learning is facilitated.

Pendapat lain dari Komalasari (2013:3) mengemukakan bahawa pembelajaran dapat didefinisikan sebagai suatu sistem atau proses pembelajaran subjek didik. pembelajar yang direncanakan atau didesain, dilaksanakan, dan dievaluasi secara sistematis agar subjek didik/pembelajar dapat mencapai tujuan-tujuan pembelajaran secara efektif dan efisien. Istilah pembelajaran dan penggunaannya masih tergolong baru, yang mulai populer semenjak lahirnya UU Sistem 
Pendidikan Nasional No.20 Tahun 2003 yang menyebutkan bahawa pembelajaran diartikan sebagai proses interaksi peserta didik dengan pendidik dan sumber belajar pada suatu lingkungan belajar.

Jadi pembelajaran merupakan bantuan yang diberikan guru agar dapat terjadi proses perolehan ilmu dan pengetahuan, serta pembentukan sikap dan kepercayaan pada siswa.

\section{Hakikat Prestasi belajar}

Berdasarkan uraian tentang konsep belajar tersebut, dapat dipahami tentang makna prestasi belajar, yaitu yaitu perubahan-perubahan yang terjadi pada diri siswa, baik yang menyangkut aspek kognitif, afektif, dan psikomotor sebagai hasil dari kegiatan belajar. Nawawi dalam K.Brahim (dalam Susanto 2013:5), menyatakan bahwa prestasi belajar dapat diartikan sebagai tingkat keberhasilan siswa dalam memsiswai materi siswa di sekolah yang dinyatakan dalam skor yang diperoleh dari hasil tes mengenal sejumlah materi siswa tertentu.

Anni (2006:5) mengemukakan bahwa prestasi belajar merupakan perubahan perilaku yang diperoleh pembelajar setelah mengalami aktivitas belajar. Perolehan aspek-aspek perubahan perilaku tersebut tergantung pada apa yang disiswai oleh pembelajar. Keberhasilan siswa setelah mengikuti satuan pembelajaran tertentu disebut dengan keberhasilan prestasi belajar (Poerwanti 2008:7.4). Keberhasilan prestasi belajar siswa ditunjukkan oleh kemampuan siswa setelah mengikuti proses pembelajaran. Oleh karena itu, keberhasilan belajar siswa dapat kita ketahui dari hasil penilaian kita terhadap hasil siswa setelah mengikuti proses pembelajaran.

Untuk mengetahui apakah prestasi belajar yang dicapai telah sesuai dengan tujuan yang dikehendaki dapat diketahui melalui evaluasi. Sebagaimana dikemukakan oleh Sunal (dalam Susanto 2013:5), bahwa evaluasi merupakan proses penggunaan informasi untuk membuat pertimbangan seberapa efektif suatu program telah memenuhi kebutuhan siswa. Evaluasi ini dapat dijadikan feedback atau tindak lanjut untuk mengukur tingkat kepuasan siswa.

\section{Metode Whats App Berbasis Group (WA Grup)}

\section{WhatsApp}

WhatsApp Messenger adalah aplikasi pesan untuk ponsel cerdas. WhatsApp Messenger merupakan aplikasi pesan lintas platform yang memungkinkan kita bertukar pesan tanpa pulsa, karena WhatsApp Messenger menggunakan paket data internet. Aplikasi WhatsApp Messenger menggunakan koneksi internet 3G, 4G atau WiFi untuk komunikasi data. Dengan menggunakan WhatsApp, kita dapat melakukan obrolan daring, berbagi file, bertukar foto dan lain-lain.

WhatsApp memiliki berbagai fitur yang dapat digunakan untuk berkomunikasi dengan bantuan layanan internet. Fitur-fitur yang terdapat dalam WhatsApp yaitu Gallery untuk menambahkan foto, Contact untuk menyisipkan kontak, Camera untuk mengambil gambar, Audio untuk mengirim pesan suara, Maps untuk mengirimkan berbagai koordinat peta, bahkan Document untuk menyisipkan file berupa dokumen. Semua file tersebut dapat dalam sekejap dikirim melalui aplikasi gratis tersebut. Berbagai fitur tersebut tentu semakin menambah kemudahan dan kenyamanan berkomunikasi melalui media online (Jumiatmoko, 2016; Aminah dkk, 2021; Syarifuddin dkk, 2021). 


\section{Manfaat WhatsApp bagi adalah:}

1) Mempermudah mahasiswa (termasuk siswa dalam konteks penelitian ini) berkomunikasi dan mencari informasi di luar jam pembelajaran.

2) Selain untuk berdiskusi, WhatsApp digunakan untuk pengumuman mengenai perkuliahan yang akan dilakukan pada jadwal selanjutnya, sehingga kita bisa sedikit belajar sebelum perkuliahan dilakukan.

3) Membuat mudah dalam bertanya dan mendapatkan informasi dengan sangat luas.

4) Lebih cepat memperoleh informasi dari mahasiswa lain maupun dosen (termasuk guru dalam konteks penelitian ini).

5) Dapat memberi atau menerima informasi perkuliahan dengan sangat cepat dan tanpa bertatap muka secara langsung.

Sebagai sarana bertukar informasi dan sarana berdiskusi baik secara personal atau berkelompok (grup).

\section{Metode Pembelajaran}

Menurut Kamus Umum Bahasa Indonesia (Poerwodarminto, 2003) metode adalah cara yang telah teratur terpikir baik-baik untuk mencapi suatu maksud. Dalam hal pembelajaran metode

Sebagaimana dikemukakan oleh Djamara (2006) bahwa idak ada satupun kegiatan pembelajaran yang tidak menggunakan metode pembelajaran. Ini bererti guru memahami benar metode sebagai alat motivasi ekstrinsik dalam kegiatan pembelajaran. Motivasi ekstrinsik menuru Sardiman (1998) adalah motif-motif yang aktif dan berfungsinya karena adanya perangsang dari luar. Apabila kehadira metode pembelajaran sangat vital maka dapat dipastikan bahwa metode pembelajaran memegang peranan penting dalam pembelajaran.

\section{Metode Tanya Jawab}

Metode tanya jawab adalah cara penyajian pelajaran dalam bentuk pertanyaan yang harus dijawab, terutama dari guru kepada siswa, tetapi dapat pula dari siswa kepada guru, atau dari siswa kepada siswa. Metode tanya jawab merupakan metode tertua bukan saja digunakan dalam pembelajaran tetapi dalam proses pendidikan, baik di lingkungan keluarga masyarakat maupun sekolah. lain:

Metode tanya jawab memiliki kelebihan dan kekurangan. Kelebihannya antara

a) Pertanyaan dapat menarik dan memusatkan perhatian siswa, sekalipun ketika itu siswa sedang rebut, yang mengantuk kembali tegar dan hilang kantuknya.

b) Merangsang siswa untuk melatih dan mengembangkan daya piker, termasuk daya ingatnya.

c) Mengembangkan keberanian dan keterampilan siswa dalam menjawab dan mengemukakan pendapat.

\section{Kekurangan Metode Tanya Jawab}

(a) Siswa merasa takut, apabila bila guru kurang dapat mendorong siswa untuk berani, dengan menciptakan suasana yang tidak tegang, melainkan akrab.

(b) Tidak mudah membuat pertanyaan yang sesuai dengan tingkat berpikir dan mudah dipahami siswa 
(c) Waktu sering terbuat, terutama apabila siswa tidak dapat menjawab pertanyaan sampai dua atau tiga orang

(d) Dalam jumlah siswa yang banyak, tidak mungkin cukup waktun untuk memberikan pertanyaan kepada setiap siswa

\section{METODE PENELITIAN}

\section{Subyek Penelitian}

Subyek perbaikan adalah siswa-siswi Kelas XI MIPA.3 SMAN 4 Kota Bima jumlah siswa 32 terdiri dari 15 orang laki-laki dan 17 orang perempuan. Adapun karakteristik siswa rata-rata memiliki intake, kemampuan akademik yang sedang. Kreativitas dan motivasi belajar siswa rata-rata rendah.

Faktor Yang diteliti. Adapun faktor-faktor yang akan diteliti adalah:

a. Prestasi belajar, sejauh mana prestasi belajar siswa dalam pembelajaran Matematika dengan penerapan metode diskusi berbasis WhatsApp group.

b. Kinerja guru, diteliti sejauh mana ketuntasan guru dalam perencanaan dan pelaksanaan pembelajaran sesuai dengan instrument yang telah ditetapkan yakni menggunakan APKG I dan APKG II.

\section{Tempat Penelitian}

Penelitian Perbaikan Pembelajaran ini dilakukan di Kelas XI MIPA.3 SMAN 4 Kota Bima.

\section{Waktu Penelitian}

Perbaikan dilaksanakan dalam 2 (dua) siklus. Siklus I dari tanggal 03 Agustus 2020 sampai dengan 18 Agustus 2020 dan siklus II dilaksanakan tanggal 8 September 2020 sampai dengan 20 September 2020.

\section{Pihak yang Membantu}

Adapun pihak-pihak yang membantu dalam penelitian ini adalah:

a) Kepala Sekolah SMAN 4 Kota Bima

b) Supervisor 2, guru senior di SMAN 4 Kota Bima

c) Guru teman sejawat, sebagai observer dalam pelaksanaan penelitian

d) Siswa SMAN 4 Kota Bima

\section{Desain Prosedur Perbaikan Pembelajaran}

\section{Gambaran Umum Perbaikan}

a. Data dan Cara Pengambilannya

1) Sumber data : sumber data perbaikan ini adalah seluruh siswa Kelas XI MIPA.3 SMAN 4 Kota Bima.

2) Jenis data :

a) Data kualitatif terdiri dari:

(1) Teacher's note (Rancangan Pembelajaran)

(2) Data hasil observasi pelaksanaan pembelajaran dan activitas siswa baik secara tatap muka maupun daring (online).

(3) Jurnal tim peneliti

b) Data Kuantitatif 
Nilai pos tes

3) Teknik Pengambilan data

(a) Data kualitatif diambil dari teacher's note (rencana pembelajaran) yang dibuat peneliti.

(b) Data tentang refleksi diri diambil dari jurnal yang dibuat oleh peneliti.

(c) Data kuantitatif diambil dari skor nilai tes siswa.

b. Indikator Kinerja

1. Prestasi belajar siswa, rata-rata nilai post test $\geq 72$ dengan porsentase ketuntasan $80 \%$.

2. Skor kinerja Guru APKG I, untuk perencanaan pembelajaran yang mendidik $\geq 89$ APKG II, untuk pelaksanaan pembelajaran yang mendidik $\geq 88$.

3. Intrumen Perbaikan

a) Instrumen perbaikan berupa performance test.

b) Lembar observasi kinerja guru.

\section{Deskripsi Per-siklus/Desain Perbaikan}

\section{a. Siklus Perbaikan}

Siklus perbaikan dilaksanakan dalam dua siklus. siklus. Tiap siklus terdiri dari 4 (empat) tahapan utama yakni: perencanaan; penerapan tindakan; observasi dan refleksi. Hasil refleksi akan menentukan apakah PTK dalam siklus tersebut berhasil atau belum berhasil. Jika belum berhasil maka akan dilanjutkan pada siklus berikutnya.

\section{b. Rincian Prosedur Perbaikan}

1) Siklus Pertama

a) Perencanaan adalah:

Dalam tahap perencanaan ini kegiatan pokok yang dilakukan

(1) Menyusun jadwal perbaikan

(2) Menyiapkan instrument pengamatan perbaikan

(3) Menyusun Rencana Pembelajaran (RPP) penerapan metode diskusi berbasis WhatsApp group untuk meningkatkan prestasi belajar siswa pada mata pelajaran Matematika materi persamaan trigonometri semester I SMAN 4 Kota Bima Tahun Pelajaran 2020/2021.

(4) Mempersiapkan materi pembelajaran persamaan trigonometri

b) Penerapan Tindakan

Melaksanakan Pembelajaran dengan mengacu pada penataan Skenario Pembelajaran penerapan metode diskusi berbasis WhatsApp group.

c) Observasi

Dalam observasi ini peneliti mengobservasi seluruh rangkaian kegiatan proses pembelajaran apakah dapat berjalan seperti yang direncanakan atau tidak. Di sini peneliti dan observer melakukan pencatatan item-item kegiatan yang secara signifikan mempengaruhi proses pembelajaran, baik yang berpengaruh positif maupun negative. Obyek observasi meliputi aktivitas guru, siswa, serta efektivitas media 
yang digunakan. Observer juga menggunakan lembar observasi dengan mengisi item-item butir observasi yang telah dipersiapkan.

Dalam observasi ini akan menentukan ketercapaian indikatorindikator utama yang menjadi tolok ukur keberhasilan perbaikan ini khususnya kemapuan membaca dan menulis siswa dan kemampuan guru dalam melaksanakan dan menyelesaikan Rencana Pembelajaran (RPP) dengan langkah pembelajaran Matematika dengan penerapan metode diskusi berbasis WhatsApp group.

d) Refleksi

Dengan menganalisa hasil observasi maka dilakukan refleksi, merenungkan kembali apa yang telah peneliti lakukan. Kegiatan refleksi ini bertujuan untuk:

1. Mengetahui dan menyimpulkan langkah-langkah manakah yang dapat berjalan seperti yang direncanakan.

2. Mengetahui dan menyimpulkan langkah-langkah manakah yang tidak dapat berjalan seperti yang direncanakan.

3. Mengetahui dan menimpulkan indikator manakah yang sudah tercapai dan indikator mana yang belum tercapai.

4. Yang paling penting adalah menentukan perbaikan pembelajaran pada siklus selanjutnya (siklus kedua). Perbaikan ini dapat mencakup aspek-aspek:
a. Pengelolaan kelas
b. Penataan skenario pembelajaran
c. Desain tes
d. Desain media pembelajaran
e. Dan temuan-temuan lainnya.

\section{Siklus Kedua}

Kegiatan pada siklus kedua merupakan rangkaian kegiatan yang tidak terpisahkan dengan kegiatan siklus pertama. Langkah-langkah kegiatan siklus kedua tidak jauh berbeda dengan siklus pertama. Disini langkah-langkah direncanakan dan dilaksanakan berdasarkan hasil refleksi Penerapan tindakan siklus pertama.

Langkah-langkah utama tersebut adalah:
a. Perencanaan
b. Penerapan tindakan
c. Observasi dan
d. Refleksi

\section{Teknik Pengumpulan dan Analisis Data}

\section{Tehnik Pengumpulan Data}

Teknik pengumpulan data kualitatif diambil melalui dokumentasi dan tes. Sedangkan pengumpulan data kuantitatif diambil melalui tes. Penjelasan tehnik pengumpulan data sebagai berikut :

a) Dokumentasi

Metode dokumentasi yaitu mencari data mengenai hal-hal atau variable yang berupa catatan lapangan, transkip, buku, surat kabar, majalah, prasasti, notulen rapat, agenda, dan sebagainya (Arikunto, 2002). 
Studi dokumentasi dilakukan untuk memperkuat data yang di peroleh dalam observasi. Dokumen yang di gunakan dalam penelitian ini berupa LKS dan daftar nilai siswa.

b) Tes

Tes adalah serentetan pertanyaan atau latihan serta alat lain yang digunakan untuk mengukur keterampilan, pengetahuan inteligensi, kemampuan atau bakat yang dimiliki oleh individu atau kelompok (Arikunto, 2002). Tes dapat digunakan untuk mengukur kemampuan dasar dan pencapaian atau prestasi belajar. Tes diberikan kepada siswa untuk mengetahui kemampuan kognitif siswa. Tes ini dikerjakan siswa secara individual setelah memsiswai suatu materi. Tes ini dilaksanakan pada saat proses pembelajaran melalui LKS dan tes akhir pembelajaran pada siklus I, siklus II.

\section{Analisis Data}

Teknik analisis data yang digunakan yaitu teknik deskriptif dengan membandingkan prestasi belajar siswa sebelum tindakan dengan prestasi belajar siswa dengan tindakan, serta membandingkan aktivitas dan prestasi belajar siswa pada siklus I dan siklus II. Data dihitung dengan langkah-langkah sebagai berikut :

Data dapat dihitung sebagai berikut :

1) Menghitung nilai rerata atau persentase prestasi belajar siswa pada siklus I dan II. Nilai rata-rata siswa dicari dengan rumus:

$$
x \frac{\sum x}{N}
$$

Keterangan :

$\mathrm{X}=$ nilai rerata

$\mathrm{N}=$ banyaknya siswa

$\sum=$ jumlah nilai seluruh siswa

2) Data tentang nilai prestasi belajar siswa

$$
\text { Tingkat penguasaan }=\frac{j m l . j a w a b a n \text { yang benar }}{\text { jml. } \text { sleluruh soal }} \times 100 \%
$$

3) Data ketuntasan prestasi belajar siswa ketuntasan belajar siswa dihitung dengan menggunakan rumus deskriptif prosentase sebagai berikut :

$$
\% \frac{n}{N} \times 100 \%
$$

Keterangan :

$\%:$ Persentase

$\mathrm{N}$ : Jumlah skor maksimal

$\mathrm{n}$ : Jumlah skor yang diperoleh dari data

4) Indikator Keberhasilah

Penelitian ini dinyatakan berhasil apabila:

a. Prestasi belajar siswa apabila rata-rata $\geq 72.00$ dengan persentase ketuntasan minimal $80.00 \%$.

b. Kinerja Guru 
Nilai kinerja guru kompetensi guru dalam perencanaan pembelajaran APKG I yakni APKG I $\geq 89.00$ dan pelaksanaan pembelajaran APKG II $\geq 88.00$.

\section{HASIL DAN PEMBAHASAN}

\section{Deskripsi Hasil Penelitian Perbaikan Pembelajaran}

\section{Hasil Perbaikan}

\section{a. Perencanaan}

Dalam penyusunan RPP tidak seperti RPP konvensional tatap muka, akan tetapi merupakan RPP penerapan metode diskusi berbasis WhatsApp group (WA Grup). Dalam penyusunan RPP dengan mempertimbangkan langkah-langkah sintaks metedo diskusi, berbasis WhatsApp group serta pengaturan, perencanaan pada langkah ke berapa digunakan tatap muka dan WhatsApp group sesuai dengan sintaksnya. Selanjutnya dalam mendesain pos tes juga tidak seperti pos tes konvensional dengan menggunakan soal yang dicetak atau difotocopy dengan lembar jawaban tertulis, melainkan dengan format tertentu dalam bentuk file yang selanjutnya di kirim lewat WA grup yang jawabannya oleh siswa dikirim melalui WA personal. Perencanaan ini menjadi strategis karena tahapan ini merupakan kunci awal keberhasilan penerapan metode diskusi dengan penggunaan WhatsApp group maka dengan cermat tahapan ini dilaksanakan khususnya dalam penyusunan RPP dengan mengacu pada Permendikbud Nomor 22 Tahun 2016 tentang Standar Proses dengan modifikasi penyesuaian seperlunya.

Langkah-langkah yang mengarah pada penggunaan pembelajaran penerapan metode diskusi berbasis WhatsApp group telah dirancang. Langkah ini harus secara bertahap sehingga ketika sampai pada penggunaan pembelajaran Zoominar dan whatsapp.

Pembelajaran penerapan metode diskusi berbasis WhatsApp group untuk mengukur keberhasilan siswa menggunakan pos tes.

Penilaian pada penerapan metode diskusi berbasis WhatsApp group tidak bisa berdiri sendiri melainkan terintegrasi dalam proses pembelajaran baik tatap muka maupun daring (online). Dengan demikian desain proses pembelajaran dengan itu sendiri juga sangat penting.

Peneliti menyusun perencaanaan ini dengan cermat sehingga perencanaan mencerminkan penerapan metode diskusi berbasis WhatsApp group.

b. Pelaksanaan Tindakan

Tabel 1. Penerapan Tindakan

\begin{tabular}{|c|c|c|c|}
\hline $\begin{array}{c}\text { Sintaks } \\
\text { (langkah-langkah) }\end{array}$ & Aktivitas & Penerapan & Catatan Pelaksanaan \\
\hline $\begin{array}{l}\text { 1. Persiapan } \\
\text { (Preparation) }\end{array}$ & $\begin{array}{l}\text { a) Mengajak siswa keluar dari } \\
\text { kondisi mental yang pasif. } \\
\text { b) Membangkitkan motivasi } \\
\text { dan minat siswa untuk belajar. } \\
\text { c) Merangsang dan menggugah } \\
\text { rasa ingin tahu siswa. } \\
\text { d) Menciptakan suasana dan } \\
\text { iklim pembelajaran yang } \\
\text { terbuka. }\end{array}$ & $\begin{array}{l}\text { Tatap } \\
\text { muka }\end{array}$ & $\begin{array}{l}\text { - Langkah preparation } \\
\text { dapat berjalan dengan } \\
\text { baik dalam hal ini untuk } \\
\text { membangkitkan motivasi } \\
\text { belajar diberikan } \\
\text { informasi dan petunjuk } \\
\text { blended learning yang } \\
\text { akan dilakukan } \\
\text { - Pembelajaran berjalan }\end{array}$ \\
\hline
\end{tabular}




\begin{tabular}{|c|c|c|c|}
\hline & & & sesuai dengan rencana \\
\hline & $\begin{array}{l}\text { 2) Penyajian (presentation) } \\
\text { Langkah penyajian adalah } \\
\text { langkah penyampaian materi } \\
\text { pelajaran sesuai dengan } \\
\text { persiapan yang telah dilakukan, } \\
\text { yang harus } \\
\text { dipikirkan oleh setiap guru } \\
\text { dalam penyajian adalah } \\
\text { bagaimana agar } \\
\text { materi pelajaran dapat mudah } \\
\text { dipahami oleh siswa. Oleh } \\
\text { karena itu } \\
\text { ada beberapa hal yang harus } \\
\text { diperhatikan dalam pelaksanaan } \\
\text { langkah ini (wina, 147): } \\
\text { a) Penggunaan bahasa } \\
\text { b) Intonasi suara } \\
\text { c) Menjaga kotak mata dengan } \\
\text { siswa. } \\
\text { d) Menggunakan joke-joke } \\
\text { yang menyegarkan. }\end{array}$ & $\begin{array}{l}\text { tatap } \\
\text { muka dan } \\
\text { daring } \\
\text { (online) }\end{array}$ & $\begin{array}{l}\text { - Langkah penyajian } \\
\text { (presentation) dilakukan } \\
\text { dengan menjelaskan } \\
\text { materi dan tanya jawab, } \\
\text { serta dibererikan contoh } \\
\text { soal dan latihan (tatapp } \\
\text { muka). } \\
\text { - Penyampaian materi juga } \\
\text { dilengkapi dengan materi } \\
\text { dalam bentuk power } \\
\text { poin yang dikirim di WA } \\
\text { grup Mata Pelajaran } \\
\text { Matematika, serta } \\
\text { diberikan latihan soal } \\
\text { dimana siswa ditugaskan } \\
\text { minimal menyelesaikan } \\
2 \text { soal dari } 5 \text { soal yang } \\
\text { diberikan. Pada langakah } \\
\text { ini } \\
\text { Tatap muka sesuii } \\
\text { dengan rencana } \\
\text { Daring (online) } \\
\text { penyelesaian soal 70\% } \\
\text { siswa mengerjakan, } 30 \% \\
\text { tidak mengerjakan }\end{array}$ \\
\hline \multirow[t]{3}{*}{ 2. Penyajian } & $\begin{array}{l}\text { 3) Menghubungkan } \\
\text { (correlation) } \\
\text { Langkah korelasi adalah yang } \\
\text { menghubungkan materi } \\
\text { pelajaran dengan pengalaman } \\
\text { siswa atau dengan hal-hal lain } \\
\text { yang } \\
\text { memungkinkan siswa dapat } \\
\text { menangkap keterkaitannya } \\
\text { dalam } \\
\text { struktur pengetahuan yang telah } \\
\text { dimilikinya. }\end{array}$ & $\begin{array}{l}\text { tatap } \\
\text { muka }\end{array}$ & $\begin{array}{l}\text { - Menghubungkan } \\
\text { (correlation) yang } \\
\text { dilaksanakan secara tatap } \\
\text { dapat berjalan dengan } \\
\text { baik. }\end{array}$ \\
\hline & $\begin{array}{l}\text { 4) Menyimpulkan } \\
\text { (generalization) } \\
\text { Menyimpulkan adalah tahapan } \\
\text { untuk memahami inti dari } \\
\text { materi pelajaran yang telah } \\
\text { disajikan. Menyimpulkan } \\
\text { berarti pula } \\
\text { memberikan keyakinan kepada } \\
\text { siswa tentang kebenaran suatu } \\
\text { paparan. Dengan demikian, } \\
\text { siswa tidak merasa ragu lagi } \\
\text { akan } \\
\text { penjelasan guru. }\end{array}$ & $\begin{array}{l}\text { tatap } \\
\text { muka dan } \\
\text { daring } \\
\text { (online) }\end{array}$ & $\begin{array}{ll}\text { - } & \begin{array}{l}\text { Menyimpulkan } \\
\text { (generalization) }\end{array} \\
\text { - } & \text { Langkah ini pada tatap } \\
\text { muka dapat erjalan } \\
\text { dengan baik, dilakukan } \\
\text { dengan lisan dan tanya } \\
\text { jawab langsung. } \\
\text { - Siswa diberikan tugas } \\
\text { untuk menyimpulkan } \\
\text { lewat WA dan dikirim } \\
\text { ke WA guru. Pada } \\
\text { langkah ini } 70 \% \text { dapat } \\
\text { mengerjakan tugas } \\
\text { dengan baik 30\% tidak } \\
\text { mengerjakan tugas. }\end{array}$ \\
\hline & $\begin{array}{l}\text { 5) Penerapan (application) } \\
\text { Langkah aplikasi adalah } \\
\text { langkah untuk kemampuan }\end{array}$ & $\begin{array}{l}\text { daring } \\
\text { (online) }\end{array}$ & $\begin{array}{l}\text { - Penerapan (application) } \\
\text { - Langkah ini dilakukan } \\
\text { dengan daring (online) }\end{array}$ \\
\hline
\end{tabular}




\begin{tabular}{|l|l|l|}
\hline & Siswa & penuh, dimana siswa \\
& setelah mereka menyimak & mengerjakan soal pos tes \\
penjelasan guru. Melalui & dengan jadwal dan \\
langkah ini guru & waktu mengerjakan soal \\
akan dapat mengumpulkan & yang ditentukan. Pada \\
informasi tentang penguasaan & & $\begin{array}{l}\text { langkah ini 50\% siswa } \\
\text { dapat menyelesaikan }\end{array}$ \\
& dan & tugas sesuai jadwal dan \\
& pemahaman materi pelajaran & waktu. 50\% siswa \\
& oleh siswa. & diberikan kelonggaran \\
& & waktu diluar jadwal. \\
\hline
\end{tabular}

Sebagaimana tabel pelaksanaan pembelajaran Dalam penerapan tindakan siklus I menunjukkan penerapan metode diskusi berbasis WhatsApp group dapat berjalan meskipun belum optimal seperti yang direncanakan.

- Pada siklus I, pelaksanaan pembelajaran yang berlangsung secara tatap muka tidak mengalami kendala. Kendala dialami pada kegiatan-kegiatan moda daring (online) dengan penggunaan WhatsApp group. Secara teknis Langkah penyajian (presentation) dilakukan dengan menjelaskan materi dan tanya jawab, serta dibererikan contoh soal dan latihan (tatap muka) berjalan sesuai rencana. Kendala muncul pada penyampaian materi juga dilengkapi dengan materi dalam bentuk power point yang dikirim di WA grup mata pelajaran Matematika, serta diberikan latihan soal dimana siswa ditugaskan minimal menyelesaikan 2 soal dari 5 soal yang diberikan. Pada langakah ini daring (online) penyelesaian soal $70 \%$ siswa mengerjakan, $30 \%$ tidak mengerjakan. Artinya pelaksanaan pembelajaran melalui daring (online) dengan penggunaan berbasis WhatsApp Messenger pada langkah ini belum optimal.

- Hambatan juga terjadi pada langkah menyimpulkan (generalization) pada pembelajaran. Pada langakah ini daring (online) penyelesaian tugas $70 \%$ siswa mengerjakan, $30 \%$ tidak mengerjakan.

- Hal yang sama terjadi pada langkah penerapan (application). Langkah ini dilakukan dengan daring (online) penuh, dimana siswa mengerjakan soal pos tes dengan jadwal dan waktu mengerjakan soal yang ditentukan. Pada langkah ini $50 \%$ siswa dapat menyelesaikan tugas sesuai jadwal dan waktu. 50\% siswa diberikan kelonggaran waktu diluar jadwal. Ini menuunjukkan bahwa pelaksanaan pembelajaran belum seerti yang diharapkan.

Adapun prestasi belajar (pos tes) dan kinerja guru siklus I dilanjutkan data prestasi belajar (pos tes) pada langkah penerapan (application). Langkah ini dilakukan dengan daring (online) penuh dan kinerja guru siklus II sebagai berikut:

Tabel 2. Nilai Prestasi belajar siswa siklus I dan siklus II

\begin{tabular}{|c|c|c|c|c|c|}
\hline \multicolumn{2}{|c|}{ Prasiklus } & \multicolumn{2}{c|}{ Siklus I } & \multicolumn{2}{c|}{ Siklus II } \\
\hline Rata-rata & $\%$ ketercapaian & Rata-rata & $\%$ ketercapaian & Rata-rata & $\%$ ketercapaian \\
\hline 65.00 & $68.00 \%$ & 68.44 & $71.00 \%$ & 75.00 & $82.00 \%$ \\
\hline
\end{tabular}

Tabel 3. Nilai Kinerja guru siklus I dan siklus II

\begin{tabular}{|c|c|c|c|c|c|}
\hline \multicolumn{2}{|c|}{ Prasiklus } & \multicolumn{2}{c|}{ Siklus I } & \multicolumn{2}{c|}{ Siklus II } \\
\hline $\begin{array}{c}\text { APKG } \\
\text { I }\end{array}$ & $\begin{array}{c}\text { APKG } \\
\text { II }\end{array}$ & $\begin{array}{c}\text { APKG } \\
\text { I }\end{array}$ & $\begin{array}{c}\text { APKG } \\
\text { II }\end{array}$ & $\begin{array}{c}\text { APKG } \\
\text { I }\end{array}$ & $\begin{array}{c}\text { APKG } \\
\text { II }\end{array}$ \\
\hline 88.00 & 85.00 & 88.5 & 86.00 & 90.00 & 89.00 \\
\hline
\end{tabular}




\section{c. Observasi}

Kegiatan observasi dilakukan oleh observer mengamati jalannya proses pembelajaran. Dalam observasi ini observer menggunakan lembar observasi dimana dalam format lembar observasi mengacu pada instrumen penilaian kinerja guru APKG I untuk perencanaan pembelajaran dan APKG II untuk pelaksanaan pembelajaran. Kompetensi guru dalam perencanaan dan melaksanakan perencanaan dan pelaksanaan pembelajaran diberikan skor dengan rentangan 1-5 dan hasil akhir dihitung dengan skor maksimal 5.

\section{Pembahasan hasil penelitian perbaikan pembelajaran}

\section{Pembahasan Siklus I}

a. Prestasi belajar

Hasil pos tes siklus I diatas menunjukkan bahwa prestasi belajar siswa rata-rata 68.44. Meskipun nilai rata-rata ini telah mengalami peningkatan dibanding sebelum diadakan perbaikan $(+3.44)$, tetapi nilai ini belum memenuhi indikator kinerja yang ditetapkan yakni rata-rata $\geq 72.00$. Persentase ketuntasan $71.00 \%$ nilai rata-rata ini telah mengalami peningkatan dibanding sebelum diadakan perbaikan $(+3.00)$, Persentase ini masih dibawah indikator kinerja yakni $\geq 80.00 \%$. Dari sisi prestasi belajar siklus I (pertama) belum berhasil.

b. Kinerja Guru

Skor kinerja guru kompetensi guru dalam perencanaan pembelajaran APKG I pada siklus $I \geq 88.50$ nilai ini mengalami penngkatan dibanding sebelum diadakan perbaikan $(+0.50)$ APKG II, untuk pelaksanaan pembelajaran yang mendidik $\geq 86.00$ meskipun nilai ini mengalami penngkatan dibanding sebelum diadakan perbaikan $(+1.00)$ tetapi masih terdapat 7 deskriptor yang sebagian dilaksanakan (sebagain terpenuhi) dan 4 deskriptor seluruhnya dilaksanakan (seluruhnya terpenuhi). Dengan demikian dari sisi kinerja guru siklus I belum mencapai indikator kinerja yang ditetapkan yakni APKG I $\geq 89.00$ APKG II $\geq 88.00$.

c. Refleksi

Data dan pembahasan diatas menunjukkan bahwa dari komponen Rencana Pembelajaran (RPP) masih perlu khususnya pada langkah pembelajaran daring (online). Belum tercapainya indikator prestasai belajar siswa faktor dominannya disebabkan guru belum mampu melaksanakan seluruh langkah-langkah yang ditetapkan dalam RPP khusunya pada kegiatan inti. Dengan demikian rencana pembelajaran perlu perbaikan atau direvisi.

Yang perlu banyak perhatian adalah pada pelaksanaan pembelajaran di kelas khususnya pada hal-hal yang berkaitan dengan kegiatan inti dan penilaian pembelajaran. Adapun yang perlu diperhatikan guru dalam perbaikan pembelajaran siklus berikutnya adalah:

1. Guru perlu memastikan bahwa siswa pada saat melaksanakan pembelajaran daring (online) dengan menggunakan WhatsApp group seluruh siswa memahami dan dapat melakukan, mengoperasikan seperti yang seharusnya.

2. Guru menyusun panduan yang jelas dan rinci di WA yang dapat memandu siswa dalam mengerjakan dan menyelesaikan tugas-tugas melaksanakan pembelajaran daring (online) dengan menggunakan WhatsApp group.

3. Guru perlu lebih intensif melakukan menitoring melaksanakan pembelajaran daring (online) dengan menggunakan WhatsApp Messenger baik di grup WA 
mata pelajaran Matematika Kelas XI MIPA.3 maupun di WA pribadi siswa yang menghadapi kendala dalam pembelajaran daring (online).

\section{Pembahasan Siklus Kedua (II)}

\section{a. Hasil perbaikan}

1) Perencanaan

Perencanaan siklus II dilakukan perbaikan pada langkah-langkah dalam kegiatan inti menyesuaikan dengan dengan mempertimbangkan hasil refleksi siklus I.

\section{2) Penerapan Tindakan}

Pembelajaran dilakukan perubahan pada langkah-langkah sesuai hasil refleksi siklus sebelumnya yakni:

1. Guru telah melaksanakan pembelajaran daring (online) dengan menggunakan WhatsApp Messenger dimana seluruh siswa memahami dan dapat melakukan, mengoperasikan seperti yang seharusnya.

2. Guru telah menyusun panduan yang jelas dan rinci di WA sehingga dapat memandu siswa dalam mengerjakan dan menyelesaikan tugas-tugas melaksanakan pembelajaran daring (online) dengan menggunakan WhatsApp Messenger.

3. Guru lebih intensif melakukan menitoring melaksanakan pembelajaran daring (online) dengan menggunakan WhatsApp Messenger baik di grup WA Mata pelajaran Matematika Kelas XI MIPA.3 maupun di WA pribadi siswa ppada yang menghadapi kendala dalam pembelajaran daring (online) sehingga kendala teknis pembelajaran daring (online) dengan menggunakan WhatsApp Messenger dapat diatasi.

\section{3) Observasi}

Dalam kegiatan ini langkah-langkah tidah jauh berbeda dengan yang dilaksanakan pada siklus I. Untuk prestasi belajar menggunakan rubrik penilaian, guna mengetahui prestasi belajar siswa dari hasil penerapan metode diskusi berbasis WhatsApp group. Observer menggunakan lembar observasi kinerja guru untuk mengamati seluruh pelaksanaan proses pembelajaran.

a) Prestasi belajar

Hasil pos tes siklus II diatas menunjukkan bahwa prestasi belajar siswa rata-rata 75.00. Nilai rata-rata ini telah mengalami peningkatan dibanding sebelum diadakan perbaikan (+6.56). Persentase ketuntasan 82. 00\%, mengalami peningkatan dibanding sebelum diadakan perbaikan $(+11.00)$. Persentase ini telah memenuhi indikator kinerja yakni $\geq 80.00 \%$. Dengan demikian pada siklus II ini telah berhasil mencapai indikator yang ditetapkan yakni rata-rata $\geq 72.00$ dan persentase ketuntasan $\geq 80.00 \%$. Dari sisi prestasi belajar siklus II (kedua) telah berhasil.

b) Kinerja guru

Skor kinerja guru menunjukkan bahwa skor ketuntasan guru dalam perencanaan pembelajaran APKG I dengan porsentase $\geq 90.00$ nilai ini mengalami peningkatan dibanding siklus I (+1.50) APKG, II untuk pelaksanaan pembelajaran yang mendidik $\geq 89.00$ nilai ini mengalami peningkatan dibanding siklus I (+3.00). Dengan perbaikan proses 
pembelajaran berhasil memenuhi indikator kinerja yang ditetapkan yakni APKG I, untuk perencanaan $\geq 89.00$ APKG II, untuk pelaksanaan $\geq 88.00$.

4) Refleksi

Dari keseluruhan analisis data dan pembahasan diatas secara umum pelaksanaan PTK penerapan metode diskusi berbasis WhatsApp group baik dari aspek prestasi belajar siswa maupun kinerja guru telah berhasil mencapai indikator kinerja yang diharapkan.

Sebagaimana dikemukakan Graham (2005) menyebutkan blended learning secara lebih sederhana sebagai pembelajaran yang mengkombinasikan antara pembelajaran online dengan face-to-face (pembelajaran tatap muka).

Tujuan akhir dari blended learning menurut Garner \&Oke (2015), pembelajaran blended learning merupakan sebuah lingkungan pembelajaran yang dirancang dengan menyatukan pembelajaran tatap muka (face to face $/ \mathrm{F} 2 \mathrm{~F}$ ) dengan pembelajaran online yang bertujuan untuk meningkatkan prestasi belajar peserta didik.

Penerapan metode diskusi berbasis WhatsApp group secara signifikan berpengaruh pada proses maupun hasil pembelajaran yang lebih komprehensif yang mampu menilai kompetensi siswa bukan saja aspek pengetahuan tetapi juga keterampilan khususnya keterampilan pembelajaran daring (online) dengan penggunaan WhatsApp Messenger dalam pembelajaran blended learning pembelajaran Matematika, hal ini ditunjukkan dengan peningkatan aktivitas, kreativitas dan motivaasi belajar siswa serta kinerja yang bermuara pada peningkatan prestasi belajar siswa.

\section{KESIMPULAN}

Kesimpulan dari hasil penelitian ini adalah: 1) Penerapan metode diskusi berbasis WhatsApp group dapat meningkatkan prestasi belajar siswa pada mata pelajaran Matematika materi persamaan trigonometri semester I Kelas XI MIPA.3 SMAN 4 Kota Bima Tahun Pelajaran 2020/2021. Penerapan Metode Diskusi Berbasis WA Grup untuk Meningkatkan Prestasi Belajar Siswa pada Mata Pelajaran Matematika Materi Persamaan Trigonometri di SMAN 4 Kota Bima Kelas XI MIPA 3 Semester Ganjil Tahun Pelajaran 2020/2021; dan 2) Penerapan metode diskusi berbasis WhatsApp group berdampak pada peningkatan kinerja guru Matematika materi persamaan trigonometri semester I Kelas XI MIPA.3 SMAN 4 Kota Bima Tahun Pelajaran 2020/2021.

Adapun saran dan tindak lanjut dari hasil penelitian ini adalah: 1) Kepada guru Matematika disarankan menerapkan metode diskusi dengan penggunaan WhatsApp Messenger dapat meningkatkan prestasi belajar siswa pada mata pelajaran Matematika materi persamaan trigonometri ataupun dikembangkan pada materi lain yang relefan; 2) Dengan penyesuaidan dan modifikasi seperlunya, kepada guru mata pelajaran lain disarankan menerapkan metode diskusi dengan penggunaan WhatsApp group dapat meningkatkan prestasi belajar dan mengatasi permasalahan pembelajaran selama pandemi covid-19; dan 3) Kepada sekolah, instansi terkait disarankan untuk dapat menyediakan fasilitas penunjang proses pembelajaran dan pengembangan pembelajaran saintifik untuk menunjang efektvitas pelaksanaan 
Kurikulum 2013 baik pada perencanaan, pelaksanaan maupun penilaian pembelajaran, khususnya pembelajaran moda daring (online).

\section{DAFTAR PUSTAKA}

Arikunto, Suharsimi. (2007). Prosedur Penelitian Suatu Pendekatan Praktek.Jakarta: Rineka Cipta.

Arikunto, Suharsimi, dkk. (2012). Penelitian Tindakan Kelas. Jakarta: Bumi Aksara.

Arikunto,S. (2008). Prosedur Penelitian Suatu Pendekatan Praktik. Jakarta: RinekaKarya.

Abidin. (2014). Desain Sistem Pembelajaran dalam Konteks Kurikulum 2013. Bandung: Refika Aditama.

Ahmad Susanto. (2013). Teori Belajar dan Pembelajaran di Sekolah Dasar. Jakarta: Kencana Prenadamedia Group.

Aminah, N., Amami, S., Wahyuni, I., \& Rosita, C. D. (2021). Pemanfaatan Teknologi Melalui Pelatihan Penggunaan Aplikasi Google Site bagi Guru MGMP Matematika SMP Kabupaten Cirebon. Bima Abdi: Jurnal Pengabdian Masyarakat, 1(1), 23-29.

Busono, G. A. (2016). Pengaruh Sistem Pelatihan Dan Pengembangan Karyawan Terhadap Kinerja Karyawan Pt. Persada Sawit Mas (PSM) Kecamatan Pampangan Kabupaten Ogan Komering Ilir.Muqtashid, 1(1), 81-114.

Bonk, C. J. dan Graham, C. (2006). The Handbook of Blended Learning. Global Perspectives, Local Design. San Fransisco : Pfeiffer.

Depdiknas. (2003). Undang-undang RI No.20 tahun 2003.tentang sistem pendidikan nasional.

Driscoll, M. (2002). Blended Learning: Let's Get Beyond the Hype. [online]. Diakses dari http://www-8.ibm.com/services/pdf/blended_learning.pdf.

Erman Suherman, dkk. (2003). Strategi Pembelajaran Matematika Kontemporer. Bandung: UPI.

Hadi, S., Tukiran, T., \& Yuwono, B. (2009). Pengaruh Supervisi Akademik, Kompetensi Guru dan Kedisiplinan Terhadap Kinerja Guru SMA Negeri 3 Slawi Kabupaten Tegal.Khazanah Pendidikan,2(1).

Heinze, A., \& Procter, C. (13-14 September, 2004). Reflections on the use of blended learning.Education in a changing environment conference proceedings: Education development unit.University of Salford, Manchester. 13 Oktober 2011, dari http://www.ece.salford.ac.uk/ proceedings/papers/ah_04.rtf.

Hamalik, Oemar. (2008). Perencanaan Pengajaran Berdasarkan Pendekatan Sistem.Jakarta: Bumi Aksara.

Hurlock, Elizabeth B. (2011). Psikologi Perkembangan : Suatu Pendekatan Sepanjang Rentang Kehidupan. Jakarta : Erlangga. 
I.G.A.K. Wardani. (2019). Pemantapan Kemampuan Profesional. Jakarta: Universitas Terbuka KTSP SD/MI 2019.

Jumiatmoko, M. (2016). Whatsapp Messenger Dalam Tinjauan Manfaat Dan Adab. Wahana Akademika: Jurnal Studi Islam Dan Sosial, 3(1), 51. https://doi.org/10.21580/wa.v3i1.872.

Komalasari, Kokom. (2013). Pembelajaran Kontekstul: Konsep dan Aplikasi. Bandung : PTRefika Adiatama.

Kementerian Pendidikan Nasional. Direktorat Jenderal Peningkatan Mutu Pendidik dan Tenaga Kependidikan. (2010). Pedoman Pelaksanaan Penilaian Kinerja Guru(PK Guru). Jakarta. www.bermutuprofesi.org.

Kartowagiran, B. (2011). Kinerja Guru Profesional (Guru Pasca Sertifikasi).Jurnal Cakrawala Pendidikan,3(3).

Minarsih, M. M. (2015). Analisis Pengaruh Kepemimpinan Transformasional, Moral Dan Komitmen Organisasi Terhadap Organizational Citizenship Behavior Dalam Meningkatkan Kinerja Guru Sekolah Dasar Swasta di Kecamatan Pedurungan Kota Semarang.Jurnal Ekonomi dan Bisnis Kontemporer,1(01).

Nuchiyah, Nunu. (2007). Pengaruh Kepemimpinan Kepala Sekolah dan Kinerja Mengajar Guru Terhadap Prestasi Belajar Siswa. Jurnal Pendidikan Dasar. Vol.5 no.7: 1-4.

Nana Sudjana. (2010). Dasar-dasar Proses Belajar, Sinar Baru Bandung.

Poerwanti, E., dkk. (2008). Asesmen Pembelajaran SD. Direktorat Jenderal Pendidikan Tinggi Depdiknas.

Padmono. (2010). Kelebihan Kekurangan Manfaat dan Penerapan PTK Seri PTK 15. [Online].Tersedia:http//m.kompasiana.com/post/edukasi/2010/10/09/Kelebihankekurangan-manfaat-dan-penerapan-PTK-seri-PTK-15/.[12 Maret 2013].

Sukintaka. (1992).Teori Bermain Untuk D2 PGSD Penjaskes.Proyek Pembinaandan Peningkatan Mutu Tenaga Kependidikan Direktorat JenderalPendidikan Tinggi. Jakarta. Departemen Pendidikan dan Kebudayaan.

Santrock (2003) John W. Adolescence. Perkembangan Remaja. Edisi Keenam. Jakarta: Erlangga.

Soedjadi. (2000). Kiat Pendidikan Matematika di Indonesia. Jakarta: Direktorat Jendral Pendidikan Tinggi Departemen Pendidikan Nasional.

Syarifuddin, S., Basri, H., Ilham, M., \& Fauziah, A. F. (2021). Efektifitas Pembelajaran Daring Mahasiswa Pendidikan Matematika ditengah Pandemi Covid-19. JagoMIPA: Jurnal Pendidikan Matematika dan IPA, 1(1), 1-8.

Winataputra, Udin S.dkk. (2008). Teori Belajar dan Pembelajaran. Jakarta: Universitas Terbuka.

Wina Sanjaya. (2009). Penelitian Tindakan Kelas. Jakarta : Kencana. 